\title{
Activities of Jalsrot Vikas Sanstha (JVS)
}

$\mathbf{J}_{\mathrm{p}}^{\mathrm{v}}$

VS Nepal is a non-profit, non-government, nonpolitical and professional organization and is incorporated under Association Registration Act 2034. Global Water Partnership (GWP) was established in August 1996 to interpret and bring into practices the internationally recognized principles.

\section{GWP Nepal/JVS organized a Consultation Meeting with National Implementing Partners/ Focal Points}

GWP Nepal/JVS organized a Consultation Meeting with National Implementing Partners/Focal Points Working on Water, Agriculture and Climate Change Sectors on 12th January 2012. The participants were from governmental, non-governmental organizations, freelancer/consultants, researchers and academicians. Rigorous discussion among participants identified and prioritized the major water related issues in agriculture in the light of climate change.

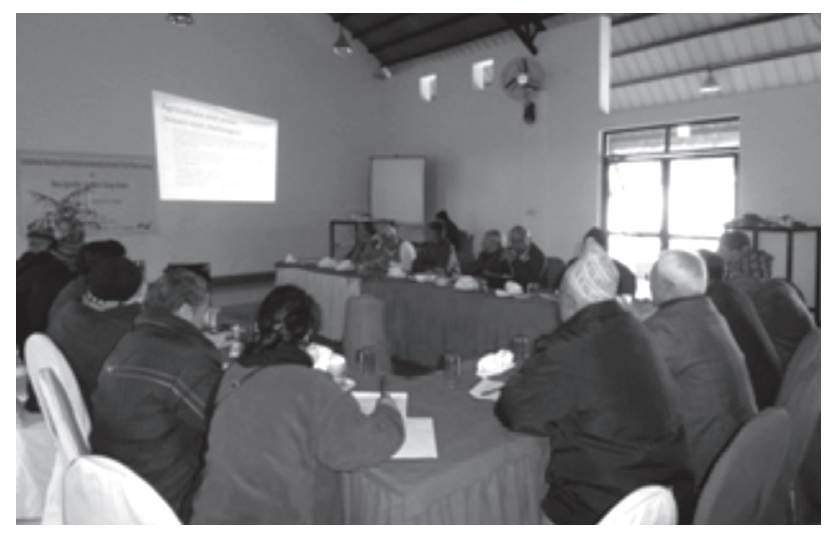

Participants during the Consultation Meeting

\section{GWP Nepal/ JVS Submits Memorandum to Prime Minister}

The Government of Nepal (GON) recently introduced a non-transparent procedure for the award of hydropower development license to the developers by replacing the one which had a transparent bidding mechanism. Similarly, the Government had split the Ministry of Water Resources (MOWR) into two parts: Ministry of Irrigation (MOI) and Ministry of Energy (MOE).

A memorandum was handed over to Rt. Honorable Prime Minister Dr. Babu Ram Bhattarai by the members of JVS led by Mr. Iswer Raj Onta and Mr. Surya Nath Upadhyay on 22nd February 2012. They requested the Prime Minister to provide necessary directions in order to maintain the transparent mechanism and a fair competition while bidding for the license. Similarly, they also drew his attention towards the integrated approach in water resources management and the need to reestablish the MOWR.

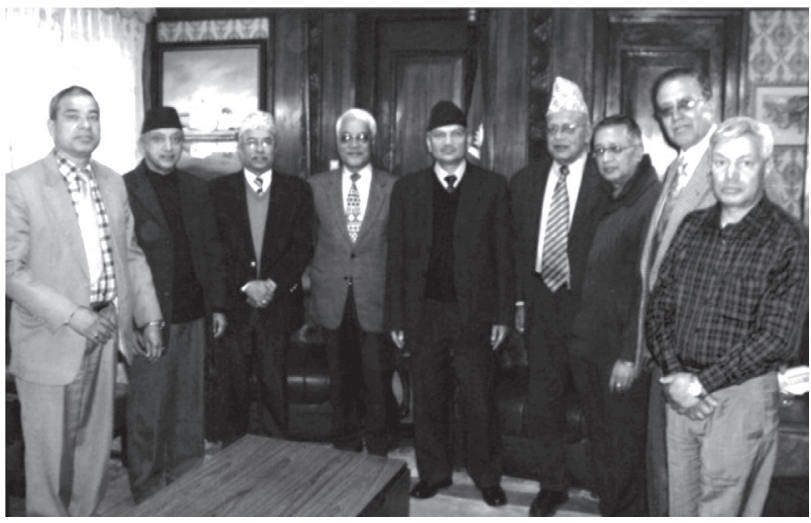

Members of JVS Nepal with Prime Minister

\section{Two Village Development Committees (VDCs) on the process of formation of Local Water Parliament}

GWP Nepal/JVS is implementing Local Water Parliament (LWP) in two VDCs of Ilam District of Eastern Development Region of Nepal. In this regard, it is helping the local community to develop Water Resources Master Plan in each VDC (Jogmai and Gorkhe VDCs) of Ilam under the Integrated Water Resources Management (IWRM) concept and National Water Plan 2005.

The training and interaction program on Rights and Responsibilities on Water Resources was held on 16th February 2012.

Mr. Surya Nath Upadhyay, Secretary General of GWP Nepal/JVS made presentation on Water Rights. Mr. Som Nath Poudel, Vice-Chair, briefed on the principles of IWRM whereas Dr. Vijaya Shrestha, Member (Executive Committee), presented on institutional aspects of Local Water Parliament and its execution. Mr. Hirakaji Ghale, President of Namsaling Community Development Center (NCDC), the local water partner of JVS, talked briefly on activities of LWP-Ilam and the role of NCDC on proper use and conservation of water resources.

\section{National Water Resources Policy}

Water and Energy Commission Secretariat (WECS) commissioned JVS/GWP Nepal for drafting National Water Resources Policy for Nepal. Mr. Surya Nath Upadhyay, Secretary General, GWP Nepal/JVS is the team leader and Mr. Som Nath Poudel, Vice Chair, GWP Nepal/JVS is the team member of the assignment.

GWP Nepal/JVS has completed the final draft policy. It aims to address the issues on water use and development conflict, non-cooperation, water rightaccess and allocation-issues which are not adequately addressed by the existing water development and use policies. 
This is an important attempt to accomplish the initiation work taken by (WECS) to fulfill the gap in the evolving water regime in terms of IWRM policy.

\section{An Initiation to Strengthen Water Integrity through Social Accountability}

A project entitled 'Strengthening Drinking Water and Sanitation Services Through Enhanced Accountability Measures' is being implemented by the GWP Nepal/ JVS in collaboration with the Centre for International Studies and Cooperation (CECI)/WB with the objective of strengthening the capacity of service users and service providers in effective use of social accountability approaches/tool through application of Citizen Report Card to improve service delivery and enhance the advocacy activities on the social accountability tool.

Six water supply and sanitation schemes from three developmental regions were selected for this study after a series of consultation with the officials of the Department of Water Supply and Sewerage (DWSS), Kathmandu Upatyaka Khanepani Limited (KUKL), and Rural Water Supply and Sanitation Fund Development Board (RWSSFDB). Citizen Report Card of each scheme will be prepared by building on the analysis report for sharing with respective service providers and users. Thus prepared Report Card could be adopted in drinking water and sanitation sector as an effective evaluation tool for measuring social accountability.

\section{Policy Dialogue}

GWP Nepal/JVS and Nepal Engineering College (NEC) jointly held a policy dialogue program on Groundwater Security in Kathmandu Valley on 20th March, 2012. As intended, the program brought together policy personnel and water professionals from relevant government and development organizations, academicians, researchers and students, to discuss the emerging issues facing the groundwater security and regulated groundwater use in Kathmandu Valley.

The presentations on state of groundwater use and commercialization of groundwater by the students and faculty members at NECled to identifying the issues facing groundwater and emerging water security concerns in Kathmandu. Various water professionals put forth their views and comments. Mr. Hari Dhakal, Chairperson, Kathmandu Valley Water Supply Management Board (KVWSMB) mollified the queries raised during the program and appreciated their concerns and suggestions.

For detailed activities of JVS, readers are requested to visit the website: www.jus-nwp.org.np 